\title{
INDEX TO VOLUME XXV, 1966
}

\author{
* indicates an abstract or a contribution to a discussion
}

Acid, anthranilic, excretion of, 556

- $\epsilon$-aminocaproic, in scleroderma, failure of, 175

, flufenamic, in rheumatoid arthritis, $* 574$

hyaluronic, in Heberden's nodes, 145

kynurenic, excretion of, 556

nicotinic, test of endogenous iron, 547

phosphastase in joint fluid, 137

uric, and public health, ${ }^{*} 478$

- , reduction of production of, in treatment of gout, 353

$\longrightarrow,-$ in serum, body weight and, 456

$\longrightarrow, \frac{}{\text { Canthenuric extimation of, } 184}$

AHERN, A. H.: see Zuckner, J., etc., 178

AKABORI, O.: see Schichikawa, K., etc., 25

Alepa, F. P.: see Peacock, A. C., etc., 567

AleXANDER, M. K.: see Jones, E. A., etc., 356

AlloPURINOL SYMPOSIUM, Supplement to Vol. 25, November, 1966. (See separate index)

- in treatment of gout, $353, * 478$

American Indians, rheumatoid arthritis in, 425

Amyloid studies, *375

Amyloidosis of spleen, *374

Anaemia in rheumatoid arthritis, $* 478,547$

ANDERSON, J. R., *573

- : see Buchanan, W. W., etc., 463

ANDREWS, F. J., *371 bis

Ankylosing spondylitis: see Spondylitis, ankylosing

ANSELL, B. M., *474

and LAWRENCE, J. S.: Fluoridation and the rheumatic diseases, 67

- : see Denman, A. M., etc., 340

-: see Fürst, C., etc., 364

- : see Ward, D. J., etc., 416

Anthranilic acid excretion, 556

Antibody, anti-viral, and rheumatoid factor in pregnant women, 327

- response in rheumatoid arthritis, *571

Antiperinuclear factor, *376

Anti-streptolysin-O, raised titre of, effect of tetracycline on duration of, in rheumatic fever, 332

Ardelt, W., KsIEZNY, S., NiEDZWIECKA-NAMYSLOWSKA, I., and BUDZYNSkI, A. Z.: Serum inhibitors of elastase, trypsin, and plasmin in chronic rheumatic diseases, 450

Arteritis associated with fibrosis, idiopathic retroperitoneal, 356

, temporal, and polymyalgia rheumatica, 203

Arthritis, erosive, and rheumatoid serology, 497

- , experimental, *477 exudates, 165

- r rheumatoid, anaemia of, $* 478,547$ $-\frac{1}{272}$, capillary resistance and skin-fold thickness in,

,-- , of cervical spine, 120

- _- and corticosteroid metabolism, 516

- - - dermal connective tissue, permeability in, 345

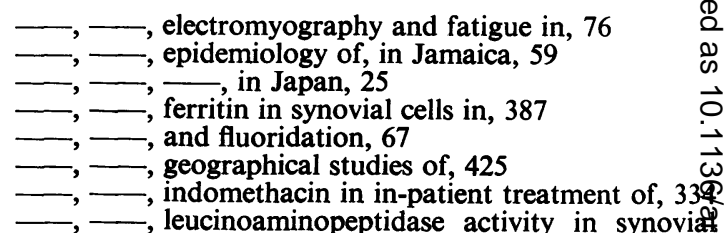

membrane in, 253

- lung changes in, 459

$\ldots,-$, in Netherlands, $* 370$

$\longrightarrow, \ldots$, and pericarditis, 235

$\ldots, \ldots$, polymyositis in, 127

$\ldots,-$, protective effect of traumatic lesions on, $36 \mathrm{~N}$

$\ldots$, protein concentration of cantharides blisters in, 422 $-\frac{1}{220}$, radiology of hands and feet and prognosis of

,-- , renal disease and drug therapy in, 441

$\ldots$, _ $\ldots$, synovectomy of knee in, 214

,-- , synovial cysts and knee joint rupture in, 3 .

,-- , temporo-mandibular joint in, 133, *369

$\ldots$, , thiotepa in, $178, * 478$

,$- \ldots$, tyrosine tolerance test in, 469

$\ldots$, urinary tryptophan metabolites in, 556

Aspirin, trial of, compared with indomethacin, 334

Autoantibody distribution in twins, 463, 574

production, hereditary and environmental facto in, $* 573$

Auto-immunization in arthritis, experimental, 165

Autoradiography of synovium with tritiated leucine, 25

$\beta$-acetylglucosaminase in joint fluid, 137

Bailey, E., Greaves, M. S., MurPHy, D., and Wes? H. F.: Corticosteroid metabolism and rheumatop arthritis, 516

BAKER, H.: Prevalence of psoriasis in polyarthrit patients and their relatives, 229

BALL, J., *143, *371, *374 bis, *376, *476 bis

see Lawrence, J. S., etc., 59

- : see Valkenburg, H. A., etc., 497

BALME, H. WYKEHAM, *252 bis

BANERJEe, N. R.: see Pitkeathly, D. A., etc., 334

BARKER, S. A., *473

, HaWkins, C. F., and Hewins, M.: Mucopol saccharides in synovial fluid. Detection of chrom droitin sulphate, 209

Barland, P., JANIS, R., and SANDSON, J.: Immun fluorescent studies of human articular cartilage, 156

BARR, M., *573 see Buchanan, W. W., etc., 463

BeardWell, C.: see Dixon, A. St.J., etc., 203

BECK, E. R., and HoFFBRAND, B. I.: Acute lung change in rheumatoid arthritis, 459

BEGG, M. W., and SCOTT, J. E.: Hyaluronic acid ang protein in simple ganglia and Heberden's nodes, 145 
BEHREND, T.: see Lawrence, J. S., etc., 425

BennetT, P. H.: see Gofton, J. P., etc., 528

- : see Lawrence, J. S., etc., 425

- : see Valkenburg, H. A., etc., 497

BERGING, G. G., *369

BERKLEY, B. B., *477

BETT, I. M.: Urinary tryptophan metabolites in rheumatoid arthritis and other diseases, 556

BIEDER, L., *478

BIER, F.: see Lawrence, J. S., etc., 1

Bio-engineering analysis of skin, 509

BITTER, T., *374

Blackfeet Indians, sacro-iliitis in, $\mathbf{5 2 8}$

Blood, aged autologous, test of endogenous iron, 547

BOERÉ, H., *375

BOOK REVIEW's:

Beetham, W. P., Polley, H. F., Slocumb, C. H., and WEAVER, W. W.: "Physical Examination of the Joints"' (1965), 85

Collins, D.: "Pathology of Bone" (1966), 575

GARDNER, D. L.: "Pathology of the Connective Tissues" (1965), 186

Neel, J. V., ShaW, M. W., and Schull, W. J. (editors): "Genetics and Epidemiology of Chronic Disease" (1964), 575

OTt, V. R. (ed.): "Der Rheumatismus. Symposium, 1964” (1965), 278

RotsteIN, J.: "Simple Splinting" (1965), 85

SÈZE, S. DE: "Connaissance élémentaire du rhumatisme" (1965), 186

Tichy, H. (ed.): “Beiträge zur Rheumatologie”, vol. 9 (1965), 85

BOURNe, W. A., *371, *372, *373, *376 bis, *515

BOYLE, J. A., *573

: see Buchanan, W. W., etc., 463

Bradley, J., *475, *476 bis

Bremner, J. M.: see Lawrence, J. S., etc., 1, 59, 425

BREWERTON, D. A., *370 quater, *371 bis, *571 bis, *573

BROWN, R., *477

BUCHANAN, I. S., *472

Buchanan, M. J.: see Isdale, I. C., etc., 184

BUCHANAN, W. W., *474, *573 bis

, Boyle, J. A., Greig, W. R., McAndrew, R., BARR, M., ANDERSON, J. R., and Goudie, R. B.: Distribution of certain autoantibodies in monozygotic and dizygotic twins, 463, 573

BudzyNSKI, A. Z.: see Ardelt, W., etc., 450

BunIM, J. J.: see O'Brien, W. M., etc., 117

Burch, T. A., O'Brien, W. M., NeEd, R., and Kurland, L. T.: Hyperuricaemia and gout in the Mariana Islands, 114

see Gofton, J. P., etc., 528

_ : see Lawrence, J. S., etc., 59, 425

__ : see O'Brien, W. M., etc., 117

_ : see Valkenburg, H. A., etc., 497

BYWATERS, E. G. L., *143, *369 ter, *370 bis, *371 ter, *372 novem, *374 bis, *375 bis, *376 bis, *472 bis, *473 bis, *570, *571 bis, *572 bis, *573 bis : see Smith, M., etc., 332

Calcification, radiological, of joint cartilage, 295

CAlicK, A.: see Herp, A., etc., 345

CALNE, R. Y., *371

Canada, ankylosing spondylitis in Haida Indians, 525

Cantharides blisters, protein concentration of, 422

Capillary resistance in rheumatoid arthritis, 272

CARDOE, N., *574

Cataract, steroid, 364

Cartilage, human articular, immunofluorescent studies of, 156 joint, radiological calcification of, 295

CATs, A.: see Korst, J. K. van der, etc., 553

Caughey, D. E., *477 ter

- see Highton, T. C., etc., 149

Caygill, J. C., *143 bis, ${ }^{*} 144$

and Pitkeathly, D. A.: A study of $\beta$-acetylglucosaminase and acid phosphatase in pathological joint fluids, 137

Chalmers, T. M., *574

Chest infection in rheumatoid arthritis, *570

Chloroquine as cause of eye lesions, $* 474$

Chondrocalcinosis articularis, *371

Chondroitin sulphate detection in synovial fluid, 209

Chondro-osteodystrophy, familial, $* 477$

Clegg, Dr. Hugh, 86

Colenbrander, H.: see Korst, J. K. van der, etc., 553

Collagen content of skin, 510

disease, nail-fold capillaries in, $* 472$

fibrils from rheumatoid joints, inter-molecular cross-linking deficiency in, 563 and serotonin, $* 478$

Conlon, P. W., Isdale, I. C., and Rose, B. S.: Rheumatoid arthritis of the cervical spine, 120

Connective tissue, dermal, permeability of, in rheumatoid arthritis, 345 , microchemical analysis of, $* 373$

- rheological analysis of, 509

Consden, R., and SMITH, M.: Protein concentration of cantharides blisters in rheumatoid arthritis, 422

Coomes, E. M.: see Pitkeathly, D. A., etc., 127

Copeman, W. S. C., *473

Corticosteroids, effect of, on capillary resistance and skin-fold thickness in rheumatoid arthritis, 272

- metabolism of, and rheumatoid arthritis, 516

Cosh, J., *369 bis, *373

Costoclavicular syndrome, $* 369$

Crane, W. A. J.: see Roy, S., etc., 259

Cregan, J. C. F.: Internal fixation of unstable cervical spine, 242, *251, *252 quater

Crews, S. J., *474 quinter

CurReY, H. L. F., *371 bis, *372 ter

, Key, J. J., Mason, R. M., and Swettenham, K. V.: Significance of radiological calcification of joint cartilage, 295

Curry, N.: see Waller, M., etc., 327

Cyst, popliteal, and rupture of knee joint, 32

CZEKAlowsKI, J. W., *571

DAVIES, D. V., *472, *473 bis

Denman, A. M., Szur, L., and Ansell, B. M.: Hyperuricaemia in polycythaemia vera, 340

DiXon, A. St.J., *252, *371

-, BeardWell, C., KaY, A., WanKa, J., and Wong, Y. T.: Polymyalgia rheumatica and temporal arteritis, 203

Disk degeneration and fluoridation, 67

Dislocation of cervical spine, internal fixation in, 242

DORNER, R. W. : see Zuckner, J., etc., 178

Drug therapy and renal disease in rheumatoid arthritis, 441

Duthie, J. J. R., *370 bis, *371, *375, *376 ter, *472, $* 474$ bis

Dwarfism, corticosteroid-induced, in Still's disease, 416

EADE, A. W. T., *372 sext, *373 bis

Elastase inhibitors, 450

Electromyography of fatigue, 76

Electronmicroscope studies, 149, 259, 318

Electronmicroscopy of synovium, 387, 402, *477 bis

Enzymes in synovial fluid, 137 
Epidemiology of ankylosing spondylitis in Queen Charlotte Islands, Canada, in 1962 and 1964, 525 of arthritis, rheumatoid, 59

of gout and hyperuricaemia in Mariana Islands, 114 of osteo-arthrosis, 1

of rheumatism in Japan, 25

in the Netherlands, *370

of rheumatoid serum factors, 497

- of sacro-iliitis in eight populations, 528

European League against Rheumatism, 478

Eye lesions due to chloroquine, ${ }^{*} 474$

FAbianek, J.: see Herp, A., etc., 345

Fatigue, electromyographic measurement of, 76

Feet, radiology of, 220

Felix-DAvies, D., *375, *376

Ferritin in synovial cells in rheumatoid arthritis, 387

Fever, rheumatic: see Rheumatism, acute

Fibrinolysis, *477

Fibrosis, idiopathic retroperitoneal, associated with arteritis, 356

Flufenamic acid in rheumatoid arthritis, *574

Fluid, synovial: see Synovial fluid

Fluoridation and the rheumatic diseases, 67

FraNKS, A. S. T., *369, *370

Fraser, J. R. E., and McCall, J. F.: Cytoplasmic spreading of human synovial cells in culture. II., 49 : see McCall, J. F., etc., 42, 52

Fürst, C., SMIleY, W. K., and ANSEll, B. M.: Steroid cataract, 364

Gairdner Foundation Awards, 1965, 89

Gamma globulin and rheumatoid factor, *474

Ganglia, hyaluronic acid and protein in, 145

GANTNER, G. E., JR. : see Zuckner, J., etc., 178

GARRETT, M., *478

Gel-diffusion precipitin analysis of synovial cell extract, 534

Genetics of hyperuricaemia in American Indians, 117

Geographical studies of rheumatoid arthritis, 425

Gilkeson, M. R.: see Waller, M., etc., 327

GHADIALLY, F. N., and RoY, S.: Ultrastructure of rabbit synovial membrane, 318

- : see Roy, S., etc., 259, 402

Glick, E. N., *573 bis

GLYN, J. H., *372, *373, *473, *572, *573 quater

GlynN, L. E.: see Phillips, J. M., etc., 165

Gofton, J. P., LAWRence, J. S., BenNetT, P. H., and BurCH, T. A.: Sacro-iliitis in eight populations, 528

—_, Robinson, H. S., and Trueman, G. E.: Ankylosing spondylitis in a Canadian Indian population, 525

- : see Lawrence, J. S., etc., 425

Gold therapy trial, *373

GoldING, J. R., *572 octem

GoodWILl, C. J., and Steggles, B. G.: Destruction of the temporo-mandibular joints, in rheumatoid arthritis, 133

GosLings, J., *373 octem

GoudIE, R. B., *573

- : see Buchanan, W. W., etc., 463

Gout, *477, *478 bis

$\longrightarrow$, allopurinol in, 353

See also Symposium Supplement to vol. 25, November, 1966 (separate index)

- epidemiology of, in Mariana islands, 114

- treated by reducing uric acid production, 353

Greaves, M. S.: see Bailey, E., etc., 516

Green serum in rheumatoid arthritis, *571
GreENWOOD, B. M.: Capillary resistance and skin-fold thickness in patients with rheumatoid arthritis? Effect of corticosteroid therapy, 272

GREIG, W. R., *573

- : see Buchanan, W. W., etc., 463

Gresson, C., *478

HAAS, W. H. D. DE, *369

Haemarthrosis, experimental, 402

Haida Indians, sacro-iliitis in, 528

HALl, A. P., and Scotr, J. T.: Synovial cysts and rupturg of the knee joint in rheumatoid arthritis, 32 -: Failure of $\epsilon$-aminocaproic acid in the treates ment of scleroderma, 175

Hamilton, E. B. D., *252, *373

Hands, radiology of, 220

Haptoglobin types in Still's disease, 567

HARRIS, R.: see Pitkeathly, D. A., etc., 334

HART, F. DudLey, *371, *372 ter, *373 bis

Hartog, M.: see Ward, D. J., etc., 416

HaWkins, C. F., *473

- see Barker, S. A., etc., 209

HAZEVOET, H. N., *375, *376 ter

HEBERDEN ORATION (1965)

Sir Austin Bradford Hill, 107

HEBERDEN SocIETY

Annual General Meeting, 1965, 369

Annual Report, 1965, 279

Library Report, 1965, 280

Officers, 1966, 86

Programme, 1966, 86

Clinical Meeting, March 25, 1966, 472

May 20, 1966, 570
Allopurinol Symposium, June, 1966 (see separato index)

Officers, 1967, 570

Programme, 1967, 570

Heberden's nodes, hyaluronic acid and protein in, 145

HenNey, C. S., *475, *476

Herp, A., Fabianek, J., Calick, A., and Pigman, W: Dermal connective tissue permeability in rheumo toid arthritis, 345

Hewrins, M.: see Barker, S. A., etc., 209

HiJMANS, W., *515

Hidmans, W., *375, *376 tions on the controlled trial, 107

Hill, A. G. S., *574

Highton, T. C., *477 quater, *478

- CAUGHeY, D. E., and RAYNS, D. G.: A ne inclusion body in rheumatoid synovia, 149

HoffBRAND, B. I.: see Beck, E. R., etc., 459

Holborow, E. J., *376

HOLDEN, G., *572

Holt, L. P.: see Williamson, N., etc., 534

Holt, P. J. L., *473 quater, *474 bis

Homan-v.D.-Heide, F., *369

Hongo, I.: see Schichikawa, K., etc. 25

Houli, Dr. Jacques, 89

How, M., *473

HowES, R., *478 bis
Human growth hormone in treatment of Still's disease, 416

Humpston, D. J., *472 quinter

Hyaluronic acid in synovial fluid as index of drug action, $* 473$

Hydroxyproline excretion in Still's disease, 416

Hydroxykynurenine excretion, 556

Hyperuricaemia, epidemiology of, in Mariana islands. 114 
, genetics of, in American Indians, 117

in polycythaemia vera, 340

IJZERLOO, J. A. G. VAN, *371 octem

Immuno-electrophoresis of synovial cell extract, 534

Immunofluorescence and human articular cartilage, 156

Immunoglobulins and rheumatoid factor, *475

Inclusion body in rheumatoid synovia, 149

Indomethacin in rheumatoid arthritis, in-patient treatment of, 334

Iridocyclitis in Still's disease, 417

Iron, endogenous, metabolism of, 547

ISDALE, I. C., *478

$\longrightarrow$, Buchanan, M. J., and Rose, B. S.: Serum uric acid estimation, Modied chemical method, 184

: see Conlon, P. W., etc., 120

Japan, rheumatic complaints in, 25

Jamaica, arthritis in, 59, 425

- , sacro-iliitis in, 528

JAMES, K.: see Williamson, N., etc., 534

JANIS, R.: see Barland, P., etc., 156

JASANI, M. K., *473

JEFFREY, M., *571

Jones, E. A., and Alexander, M. K.: Idiopathic retroperitoneal fibrosis associated with an arteritis, 356

Kaklamanis, P.: see Phillips, J. M., etc., 165

KALliomÄKI, J. L., LehtoNEN, A., and SePPÄLÄ, P.: Oral tyrosine tolerance test in rheumatoid arthritis, 469

KamermanN, J. S.: Protective effect of traumatic lesions on rheumatoid arthritis, 361

KAY, A.: see Dixon, A. St.J., etc., 203

Kellgren, J. H., *369, *370, *472, *474, *476, *570

Kennedy Research Institute of Rheumatology, 278

KERSLEY, G. D.: Treatment of gout by reduction of uric acid production, 353 *371, *373, *474

KEY, J. J.: see Currey, H. L. F., etc., 295

Kidney disease and drug therapy in rheumatoid arthritis, 441

- fluoridation, 67

_ transplant followed by pseudo-gout, *371

KIEVITS, J. H., *375

Knee joint, rupture of, 32

- synovectomy, of in rheumatoid arthritis, 214

Komatsubara, Y.: see Schichikawa, K., etc., 25

KORST, J. K., vaN DER, Colenbrander, H., and CATS, A.: Phenobarbital and the shoulder-hand syndrome, 553

KosugI, T.: see Schichikawa, K., 25

Kř́žEK, V.: Serum uric acid in relation to body weight, 456

KsIEZNY, S.: see Ardelt, W., etc., 450

Kurland, L. T.: see Burch, T. A., etc., 114

Kynurenic acid excretion, 556

Kynurenine excretion, 556

Langer's lines, 510

Latex-fixation titres in a rural population, 497

LATHAM, B. A.: Pericarditis associated with rheumatoid arthritis, 235

Latitude, geographical, and rheumatoid arthritis, 425

LAWRENCE, J. S., *570 bis, *572, *573, *574

-, Bremner, J. M., BALL, J., and BURCH, T. A.: Rheumatoid arthritis in a subtropical population, 59

$\longrightarrow$, and BIER, F.: Osteo-arthrosis: Prevalence in the population and relationship between symptoms and $x$-ray changes, 1
-, Behrend, T., Bennett, P. H., Bremner, J. M., BurCH, T. A., Gofton, J., O'Brien, W., and RoBInson, H.: Geographical studies of rheumatoid arthritis, 425

— : see Ansell, B. M., etc., 67

: see Gofton, J. P., etc., 528

- : see Valkenburg, H. A., etc., 497

LAwson, A. A. H.: see Owen, E. T., etc., 547

and Maclean, N.: Renal disease and drug therapy in rheumatoid arthritis, 441

L.E.-cell phenomenon, *375

LeHtonen, A.: see Kalliomäki, J. L., etc., 469

Leigh, Lancs., sacro-iliitis in, 528

Lenman, J. A. R., and PotTer, J. L.: Electromyographic measurement of fatigue in rheumatoid arthritis and neuromuscular disease, 76

. Leucine, tritiated, autoradiography of synovial membrane with, 259

Leucinoaminopeptidase activity in synovial membrane, 253

LING, N. R.: see Williamson, N., etc., 534

Ligue Internationale contre le Rhumatisme

XI International Congress, Argentina, 1965 (Report), 86

LOEWI, G., *374 bis, *375 bis

LONG, V., *473

LOUGHRIDGE, L. W., *371, *372 octem

Lumbar disk degeneration, *571

Lung changes in rheumatoid arthritis, 459

MCANDREW, R., *573

: see Buchanan, W. W., etc., 463

McCall, J. F., and FraSER, J. R. E.: Cytoplasmico spreading of human synovial cells in culture으 I., 42

III., 52

- - : see Fraser, J. R. E., etc., 49

Maclagan, N. F., *476

MACleAN, N.: see Lawson, A. A. H., etc., 441

Manchester, sacro-iliitis in, 528

MANDEMA, E.. *375 bis, *376

Mariana Islands, gout and hyperuricaemia in, 114

MASON, R. M., *373

- - : see Currey, H. L. F., etc., 295

Mattingly, S.: Palindromic rheumatism, 307

MAYEDA, A.: see Schichikawa, K., etc., 25

MEIKLE, J. A. K., *574

__-: see Wilkinson, M., etc., 433, 574

MEINERS, W. B. H., *371

Metabolism of corticosteroids and rheumatoid arthritis, 516

__ of endogenous iron, 547

_ of human IgM and rheumatoid factor, *475

Metacarpal heads, radiography of, $* 370$

MidDleton, P. J., *477

MidDlestoN, B. J., *477

MiYaUCHI, T.: see Schichikawa, K., etc., 25

Morning stiffness, *571

Morphology of synovial cells, 534

Mucopolysaccharides in amyloidosis of human spleen, *374

in synovial fluid. Detection of chondroitin sulphate, 209

MUIR, H., *374 bis, *375, *515

MUIRDEN, K. D.: Ferritin in synovial cells in patients with rheumatoid arthritis, 387

MurPhy, D.: see Bailey, E., etc., 516

Mycoplasma infection and rheumatic disease, $* 477$

MYERS, D. B., *478

Myositis ossificans progressiva, *372 
Nail-fold capillary studies in collagen disease, $* 472$

NAYLOR, A., *571, *572

NEED, R.: see Burch, T. A., etc., 114

Netherlands, rheumatoid arthritis and osteo-arthritis in, *370

Neuropathy, rheumatoid peripheral, $* 572$

New England Rheumatism Society, 575

New York Rheumatism Association, 376, 496 (correction)

New Zealand Arthritis and Rheumatism Council, 477

NEWTON, D. R. L., *573 bis, *574 bis

Nicotinic acid test of endogenous iron, 547

NiEDZWIECKA-NAMSLOWSKA, I.: see Ardelt, W., etc., 450

NIENHUIS, R. L. F., *376 quint

NORMANSELL, D. E., *474, *476

Obesity and serum uric acid, 456

O'Brien, W. M., BurCh, T. A., and Bunim, J. J.: Genetics of hyperuricaemia in Blackfeet and Pima Indians, 117

- : see Burch, T. A., etc., 114

- see Lawrence, J. S., etc., 425

OrIHARA, M.: see Schichikawa, K., etc., 25

Osteo-arthritis, incidence of, after anterior poliomyelitis, $* 572$ in Netherlands, *370

Osteo-arthrosis, epidemiology of, in England, 1 and fluoridation, 67

- , symptoms of, and $x$-ray changes, 1

Osteoporosis and fluoridation, 67

OWEN, E. T., and LAWSON, A. A. H.: Nature of anaemia of rheumatoid arthritis. VI. Metabolism of endogenous iron, 547

PAlfrey, A. J., *472, *473 ter

PAYNe, R. B., *571

Peacock, A. C., and Alepa, F. P.: Haptoglobin types in patients with juvenile rheumatoid arthritis, 567

Penning, L., *369

Pericarditis and rheumatoid arthritis, 235

Phenacetin and renal disease, 441

Phenobarbital and shoulder-hand syndrome, 553

Phillips, J. M., Kaklamanis, P., and GlYNN, L. E.: Experimental arthritis associated with autoimmunization to inflammatory exudates, 165

Pigman, W.: see Herp, A., etc., 345

Pima Indians, sacro-iliitis in, 528

Pit Keathley, D. A., *572

-, BANerJee, N. R., HARRIS, R., and SHARP, J.: Indomethacin in in-patient treatment of rheumatoid arthritis, 334

- and COOMES, E. M.: Polymyositis in rheumatoid arthritis, 127

- : see Caygill, J. C., etc., 137

Plasmin inhibitors, 450

PlatT, G., *251

PlunketT, T. G., *571 bis, *572

Poliomyelitis, incidence of osteo-arthritis and rheumatoid arthritis after, *572, *573

Polyarthritis and psoriasis, familial study, 229

Polycythaemia vera, hyperuricaemia in, 340

Polymyalgia rheumatica and temporal arteritis, 203

Polymyositis in arthritis, rheumatoid, 127

Population studies of rheumatoid arthritis, 425

PotTeR, J. L.: see Lenman, J. A. R., etc., 76

Pregnancy, anti-viral antibodiés and rheumatoid factor in, 327

PrIOR, I. A. M., *478

Protein concentration of cantharides blisters, 422

in Heberden's nodes, 145

- synthesis of synovial cells, 534
Pseudo-gout after kidney transplant, *371

Psoriasis in polyarthritic patients and their relatives, 2293

Pyridone excretion, 556

Race and rheumatoid arthritis, 425

Radiography of metacarpal heads, $* 370$ synovial cells in ${ }^{14}$

lysine, 534
Radiology of hands and feet in prognosis of rheumatoid arthritis, 220

- of osteo-arthrosis, 1

RAJAN, K. T., *574 ter

RAMSEY, R. H.: see Zuckner, J., etc., 178

RAYNS, D. E.: see Highton, T. C., etc., 149

RAYNS, D. L., *477 bis

REAH, T. G., *570 ter

Renal clearance of cortisol and prednisolone, 516

Rheological analysis of connective tissue, 509

Rheology of synovial fluid, $* 472$

Rheumatism, acute, effect of tetracycline on duration of raised ASO titre in, 332

$\longrightarrow$, palindromic, 307

Rheumatoid arthritis: see Arthritis, rheumatoid factor, *474, *475 bis

- and anti-viral antibodies in pregnancy, 327

- in twins, 463, 574

_ in a rural population, 497

RIDGE, M. D., *515 ter and WRIGHT, V.: Rheological analysis of connecs tive tissue, 509

Robinson, H. S.: see Gofton, J. P., etc., 525

- : see Lawrence, J. S., etc., 425

RoITT, I., *476

Rose, B. S., *477, *478

- see Conlon, P. W., etc., 120

Roy, S., and GHadially, F. N.: Pathology of experfio mental haemarthrosis, 402

,-- , and CRANE, W. A. J.: Synovial membrane iro traumatic effusion. Ultrastructure and auto radiography with tritiated leucine, 259

- : see Ghadially, F. N., etc., 318

RUINEN, L., *375 sept

Sacro-iliac joints, tomography of, 433, 574

Sacro-iliitis in eight populations, 528

Salicylates and renal disease, 441

SANDSON, J.: see Barland, P., etc., 156

SAVAGE, O., *474, *571

SCHICHIKAWA, K., MaYeda, A., Komatsubara, Y.o Yamamoto, T., AKabori, O., Hongo, I., Kosug! T., MIYauchi, T., ORIHARA, M., and Taniguchiß A.: Rheumatic complains in urban and ruras populations in Osaka, 25

ScholTEN, J. H., *375

Scleroderma, $\epsilon$-aminocaproic acid in, failure of, 175

ScoTt, J. T., *369, *372, *373, *477, *571, *574 bis (editor): Symposium on Allopurinol (see separate index)

- : see Begg, M. W., etc., 145

-

SEPPÄLÄ, P.: see Kalliomäki, J. L., etc., 469

Serology of human synovial cells, $42,49,52$

- , rheumatoid, in a rural population, 497

Serotonin and collagen, $* 478$

Serum inhibitors of elastase, trypsin, and plasmin if rheumatic disease, 450

- uric acid and body weight, 456

-1 , estimation of, 184

SEVER, J.: see Waller, M., etc., 327 
SHAH, K. D., *571 bis

SHARP, J., *372

- : see Pitkeathly, D. A., etc., 334

Sheep cell agglutination titres in a rural population, 497

Shoulder-hand syndrome, phenobarbital and, 553

Simmonds, H. A., *478

Simon, G.: see Thould, A. K., etc., 220

Skin, bio-engineering analysis of, 509

permeability in rheumatoid arthritics, 345

Skin-fold thickness in rheumatoid arthritis, 272

Smiley, W. K. : see Fürst, C., etc., 364

Smith, M.: see Consden, R., etc., 422

- and BYWATERS, E. G. L.: Effect of tetracycline on the duration of a raised antistreptolysin-O titre in rheumatic fever, 332

Spine, cervical, arthritis of, 120

$\underset{\text { SociETIES }}{-}$, unstable, internal fixation of, 242

European League, 478

Heberden Society, 86, 107, 279, 369, 472, 570

See also Allopurinol Symposium, Supplement to vol. 25, November, 1966 (Separate index)

International League, 86

New England Rheumatism Society, 575

New York Rheumatism Association, 377

New Zealand Rheumatism Association, 477

Spleen, human, amyloidosis of, *374

Spondylitis, ankylosing, in Canadian Indians (Haidas) in 1962 and 1964,525

STANWORTH, D. R., *475, *476 bis

Starch-gel electrophoresis of synovial cell extract, 534

STEGGles, B. G.: see Goodwill, C. J., etc., 133

STEINBERG, V. L., *252, *572

Steroid therapy as cause of cataract, 364 and renal disease, 441

STEVEN, F. S.: Evidence for a deficiency in inter-molecular cross-linking in collagen fibrils isolated from rheumatoid joints, 563

Stevens, J., and Whitefield, G. A.: Synovectomy of the knee in rheumatoid arthritis, 214

Still's disease, haptoglobin types in, 567

- , hydroxyproline excretion in, 416 costeroid-induced dwarfism in, 416

STOCKWELL, ?., *374

Subluxation of cervical spine, internal fixation in, 242

Surgery of unstable cervical spine, 242

SWeTtenham, K. V.: see Currey, H. L. F., etc., 295

Synovectomy of knee in rheumatoid arthritis, 214

Synovial cells, morphology and protein synthesis of, 534

fluid, chondroitin sulphate in, 209

—_ corticosteroid metabolites in, 516

- _ enzymes of, 137

${ }_{* 473}$, hyaluronic acid in, as index of drug action,

$-\frac{473}{-}$, rheology of, $* 472$

Synovium cells, human, cytoplasmic spreading of, in culture, 42, 49, 52

- cysts of, and rupture of knee joint, 32

- electronmicroscopy of, $* 477$ bis

— in experimental haemarthrosis, 402

- , ferritin in, 387

_- leucinoaminopeptidase activity in, 253

(rabbit), ultrastructure of, 318

rheumatoid, new inclusion body in, 149

- in traumatic effusion, 259

SzIRMAI, J. A., *373, *374 quint, *515

Szur, L.: see Denman, A. M., etc., 340

TANIGUCHI, A.: see Schichikawa, K., etc., 25
Temporomandibular joint, *369

- destruction in arthritis, 133

Tetracycline and duration of raised ASO titre in rheumatic fever, 332

Thiotepa, *478

- intra-articular, in rheumatoid arthritis, 178

THOMPSON, M., *574

Thould, A. K., and Simon, G.: Assessment of radiological changes in hands and feet in rheumatoid arthritis, 220

Tomography of sacro-iliac joints, 433, 574

Trauma, protective effect of, in rheumatoid arthritis, 361

Trial, controlled, in medical research, 107

Trueman, G. E.: see Gofton, J. P., etc., 525

Trypsin inhibitors, 450

Tryptophan metabolites, urinary, in arthritis, rheumatoid, 556

Twins, autoantibody distribution in, 463, 574

UDDIN, J.: see Zuckner, J., etc., 178

Ultrastructure of rabbit synovial membrane, 318 of synovium in traumatic effusion, 259

Urinary clearance of cortisol and prednisolone, 516

VAlkenburG, H. A., *370 ter

-, Ball, J., BurCh, T. A., BennetT, P. H., and LAURENCE, J. S.: Rheumatoid factors in a rural population, 497

VAINIO, U.: Histochemical study on leucinoaminopeptidase activity in synovial membrane of patients with rheumatoid arthritis, 253

WALKER, G. F., *572

WALKER, W. C., *570 ter

Waller, M., Sever, J., Curry, N., and Gilkeson, M. R.: Relationship between viral antibodies and rheumatoid factor in pregnant women, 327

Wanka, J.: see Dixon, A. St.J., etc., 203

Ward, D. J., Hartog, M., and Ansell, B. M.: Corticosteroid-induced dwarfism in Still's disease treated with human growth hormone, 416

Watford, England, sacro-iliitis in, 528

WATKINS, B. G., *369

Wensleydale, sacro-iliitis in, 528

- , rheumatoid serum factors in population of, 497

WeST, H. F.: see Bailey, E., etc., 516

Whitefield, G. A.: see Stevens, J., etc., 214

WIGLEY, R. D., *477, *478

WILKINSON, M., *574

- and MeIKLE, J. A. K.: Tomography of the sacroiliac joints, 433,574

Williamson, N., James, K., Ling, N. R., and Holt, L. P.: Synovial cells, morphology and protein synthesis of, 534

WiLSON, J. D., *478

WILSON, J. V., *570 bis

WoNG, Y. T.: see Dixon, A. St.J., etc., 203

WoudA, A. A., *369 quater

WrIGHT, V., *143, *372, *373, *473, *571 sext, *572 bis, $* 573, * 574$

—_: see Ridge, M. D., etc., 509

Xanthurenic acid excretion, 556

Yамамото, T.: see Schichikawa, K., etc., 25

ZuCKNER, J., UdDin, J., RAMSEY, R. H., GANTNER, G. E., JR., AHERN, A. M., and DorNer, R. W.: Evaluation of intra-articular thio-tepa in rheumatoid arthritis, 178 


\section{INDEX TO SUBJECTS OF ARTICLES ABSTRACTED}

* indicates that only the title of the article is given

Acid, amino, in hyperuricaemia, 93

_-, uric, miscible pool of, in hyperuricaemia, 577

ACTH, mechanism of action of, 490 therapy, 104

- , tritiated, metabolism of, 490

Adrenal glands, immunology of, 100 hormone therapy, 103

- response to "Synacthen", 198

Agglutination studies, 384

Alkaptonuria, 485

Allopurinol in gout, 94

Amikapron, *491

Aminophenazole, *293

Amyloid, tests for, 102 bis

Amyloidosis, 92

with colitis in spondylitis, *482

— and lung tumours, $* 581$

Anaemia, aplastic, due to phenylbutazone, 494

Ankylosing spondylitis: see Spondylitis, ankylosing

Antibodies, tissue, in lupus erythematosus, 578

Anti-nuclear factor, 100, *102, 196, 197 in leprosy, 382

Antistreptolysin reaction, *384

Arechin, eye lesions due to, $* 580$

Arteriography in diagnosis of osteo-arthropathy of hand, 581

Arteritis, cerebral, *488

in lupus erythematosus, systemic, 192

- necrotizing, with haemolytic anaenia, 193

$\ldots$, temporal, 99

,-- , indomethacin therapy and, $* 200$

___ _ _ neuro-ophthalmological aspect of, 578

$\ldots,-$, polymyalgia rheumatica and, $381, * 488$

$\ldots$ - w with scalp ulceration, 482

Arthritis, adjuvant-induced, 101

- , bacterial, of hip, 93

,$- \ldots$, of shoulder, 283

- experimental, 100, 101, *102, 384,*490

, gouty, 483, *485 bis

immunosuppressive drugs in, $* 200$

psoriatic, immuno-electrophoresis in, ${ }^{*} 102$

rheumatoid, amyloid nephrosis in, 92

, cardiovascular system in, $* 481$

,$- \ldots$, of cervical spine, $92, * 283$ Charcot-like arthropathy in, 188

,-- , clinical studies of, 282

_ _ _ - early radiology of, 188

$\ldots, \ldots$, fibrocartilage in, *189

-_, - genetic study of, 92

$\ldots \ldots, \ldots$, gluten and small intestine in, $* 481$ bis

__, _- gold therapy of, $188 \mathrm{bis}$

$\ldots, \ldots$, hand deformity in, $* 283$

$\ldots$ __ _ and Hashimoto's thyroiditis, *283

$\ldots, \ldots$, indomethacin in, 198

$\ldots,-$, kidney biopsy in, 480

$\ldots$, -

$\ldots$, , with L.E.-cells, 576
,,-- leg ulcers in, 92

,,-- linear subcutaneous bands in, 187

$\ldots,-$, lung disease in, 91,92

$\ldots, \ldots$, mycoplasma studies in, 99

, neurological and encephalographical studies $\vec{\omega}$ in, $* 294$

,,-- peripheral neuropathy in, 91, 188

$\ldots, \ldots,-$ vascular lesions in, 480

$\ldots$, , pleurisy in, ${ }^{*} 189$

,$- \ldots$, serum albumin studies in, 481

$\ldots, \ldots$, in shoulder, $* 481$

- _ _ , surgery of interphalangeal joints in, 496

, taste perception in, *282, *294

of ulcerative colitis, $283, * 285$

Arthrodesis of hip, 92, 495

of shoulder, $* 200$

Arthro-ophthalmopathy, hereditary progressive, 201

Arthropathy, psoriatic, $* 483$

Arthrosis, disk and inter-apophyseal, *283

Aspirin with chloroquine and prednisone, $* 580$

Atlanto-axial dislocation in rheumatoid arthritis, *481 옿요

Auto-immune disease, experimental, 579

Auto-immunity and Dupuytren's contracture, 577

$\beta^{1-24}$-corticotrophin (Ciba 30'920-Ba): Synacthen, 198

Behçet's disease, 483 bis

$\ldots$, cutaneous signs of, *284

presenting as rheumatic fever, 90

Betamethasone, intermittent therapy with, $* 200$

Biopsy of kidney in rheumatoid arthritis, 480

Blood clotting in collagen disease, $* 490$

Bone, fibrous dysplasia of, $* 380$

Bones, effect of cold and damp on, 488

Brucellosis, mesenchymopathy of, *491

Bursa, subacromial, injection of, *496

Calcaneitis, $* 581$

Calciuria and uraturia, *491

Cancer after radiotherapy of spondylitis, 495

Carditis, rheumatic, activity tests of, $* 282$

,-- , co-operative clinical trial of therapy of, 28

,$- \ldots$, prolonged massive steroid therapy of, $* 580$

$\ldots$, , radiology of, in children, $* 282$

,-- , serum lactic dehydrogenase test of, 479

Carpal-tunnel syndrome, 486

Cartilage, articular, biology of, *194

$\longrightarrow$, degeneration, salicylate inhibition of, $* 195$

, interstitial fluid of, *103

Cataract, steroid, 199

Charcot-like arthropathy in rheumatoid arthritis, 188

Children, ankylosing spondylitis in, 189

-

_

, rheumatoid arthritis in: see Still's disease

Chloroquine, anti-inflammatory effect of, 105

with aspirin and prednisone, $* 580$ 
- as cause of eye lesions, 105 quater, $106 \mathrm{sept}, 200 \mathrm{bis}$, 292 quinter, 495 bis

Chondroitin sulphate inhibition by Puromycin, *198

Chorea, Sydenham's, 90

Chromatography, *491 ter

Chromosomes, abnormalities of, and osteo-arthropathy, 577

Colchicine in gout, 95

Colitis, ulcerative, with amyloidosis in spondylitis, *482

,-- , arthritis of, 283

$\ldots, \ldots$, and sacro-iliitis, 284

,$- \ldots$, spondylitis and uveitis in, 93

Collagen antigens, *384

biosynthesis, 578

disease, cytostatic therapy of, 288

- —

- - digestive tract in, 192

- solubility in lathyrism, 194

Connective tissue, biochemistry of, 194 disease, respiratory studies in, 97

—— lesions, 382

Corticosteroids, percutaneous absorption of, 291

, topical, and osteo-arthritic changes, 291

Corticosterone secretion, 197

Cortisol acetate studies, $* 198$

determination in urine, 491

_- glaucoma due to, 199 bis, 494, 495

and immune response, 579

- metabolism, 102, 290

C-reactive protein antisera, 289

Cyclophosphamide, 494

Deafness in polyarteritis nodosa, *289

due to salicylates, 293

Dexamethasone therapy, 492, *496

Diabetes and gout, 485 bis and neural osteopathy, *581

Dimethyl sulphoxide therapy, 103

Disk arthrosis, *283

Diuretics, blood studies and, 483

in hyperuricaemia, *191

Dupuytren's contracture, 380

- 2 as auto-immune disease, 577

- _ and retinal detachment, 286

Dye transport across granuloma pouch wall, ${ }^{*} 103$

Elderly, rhizomelic pseudopolyarthritis in, *189

Electromyography in arthritis, 378

Electronmicroscopy of synovium, *382

Electrophoresis, 102 bis

Encephalitis after steroid withdrawal, *293

Encephalography of Behçet's disease, 284

of collagen disease, ${ }^{*} 294$

Endarteritis, rheumatic, 187

Endomyocarditis, rheumatic, uncommon diastolic murmur in, *187

Epidemiology of osteoporosis, 95

- of rheumatism, $* 581$

- acute, 281

Erythema nodosum in children, 578

Erythrocyte sedimentation, post-heparin, *290

Eye lesions due to Arechin, *580

due to chloroquine, 292 quint

_- in collagen disease, 99 bis quater, 200 bis, 291 bis, 292 bis and Dupuytren's contracture, 286

- of gout, $* 485$

- in lupus erythematosus, 192, 487 bis in periarteritis, $193 \mathrm{ter}, 487$

in spondylitis, ankylosing, 283

in temporal arteritis, 578

Family study of arthritis and lupus erythematosus, 386 transmission of streptococcal infection, *480

Felty's syndrome, *581

Fever, rheumatic: see Rheumatism, acute

Fibrocartilage, interarticular, in rheumatoid arthritis, *189

Fibrosis, pulmonary, in rheumatoid arthritis, 92

- , serology of, 383

Fluid, synovial, in gout, 93

Fluorescence studies of cortisol in urine, 291

Foot, osteo-arthritis of, $* 283$

Foundry workers, rheumatism in, 580

Fracture-dislocation of cervical spine in spondylitis, 482

Gamma globulin studies, 100, *101, 196 bis, 489 quater

Genetics in rheumatoid arthritis, 92

Gilbert-Behçet's disease, 190

Glaucoma, steroid, 199 bis, 494, 495

Glomerulonephritis, immunosuppressive therapy of, 494

Gluten and small intestine in rheumatoid arthritis, *481 bis

Glycocorticoid therapy of rheumatic fever, *480

Glycoproteins in children with rheumatic fever, *187

Gold salt studies, *491

- therapy of knee effusion, 493, *496

- of rheumatoid arthritis, 188 bis

Gonarthritis, juvenile rheumatoid, 481 bis

Gout, *191 ter, *285

—_, acute, due to starvation, 484

_, allopurinol in, 94

__, anticoagulants in, 190

, atypical, $* 485$

_, carbohydrate metabolism in, *285

- , colchicine in, 95

$\ldots$, eye lesions of, $* 485$

__ with hyperparathyroidism, 93

_

- in Polynesia, 485

—, renal studies in, 94

_., sacro-iliac, 577

_- , serum uric acid values in, 190

_. urinary ammonium excretion in, 483

Granulocyte studies, *290

Granuloma, rheumatoid, 187

Haemagglutination studies, 100, 101, *102 bis

Hand, arteriography in diagnosis of osteo-arthropathy of, ${ }^{*} 581$

$\ldots$, intrasynovial hydrocortisone in, *496

_.

,-- , deformities of, $199, * 283$

$\ldots, \ldots$, nodose tendinitis in, $* 200$

$\ldots$, surgery of, 104,496

- , strength of, measurement of, *496

Haptoglobin in synovial fluid, 194

Hargraves cells: see L.E.-cells

Hashimoto's disease with Sjögren's syndrome, 580

- thyroiditis, $91, * 283$

Hexadimethrine bromide, action of, *496

Hip, arthrodesis of, 92, 495

, bacterial arthritis of, 93

_- osteo-arthritis of, *189 bis, 482 ter

$\ldots, \ldots$, indomethacin in, $* 580$ bis

$\ldots, \ldots$, phlebography in, 577

$\ldots, \ldots$, surgery in, 496

- periarthritis of, $* 486$

Histamine therapy, *496 
Hyaluronate protein in synovial membrane, *195

Hydrocortisone, intrasynovial, in wrist and hand, *496

Hydroxyproline-containing protein, plasma levels of, in fever and inflammation, 579

- deficient protein, accumulation of, during collagen biosynthesis, 578

Hydroxyprolinuria in secondary bone cancer, *486

Hyodian apparatus, *581

Hyperlipaemia, diabetes, and gout, *485

Hyperparathyroidism and gout, 93

Hypertension and hyperuricaemia, 484

Hyperuricaemia, 190, *191, *285, 484 bis, 485

$\longrightarrow$, amino acid studies in, 93

_ miscible pool of uric acid in, 577

, thiazide, correction of, $* 379$

Hypoalbuminaemia, 197

Hypothyroidism, 91

Ibufenac, clinical trial of, $* 580$

Ileitis, regional, and joint disorder, $* 285$

Immunoconglutinin, $* 490$

Immuno-electrophoresis, *490

Immunofluorescence in study of skin lesions in lupus erythematosus, 578

Immunology of steroid therapy, 289

Immunopathology of lupus erythematosus, 192

Indomethacin, 104, 198 bis, *200 quinter, $* 293,377,385$, $491,492, * 580$ bis

Iridocyclitis in Still's disease, 283

Iron metabolism, 102

Jaccoud's syndrome, $* 483$

Jaffé-Lichtenstein's fibrous dysplasia of bone, $* 380$

Joint disease, degenerative, treatment of, *496

Joplin's prednisone-glycosuria test in gout, *285

Karachi, rheumatic fever in, $* 480$

Kenya, polyarthritis in, 577

Kidney biopsy in rheumatoid arthritis, 480 in Still's disease, *482

- in gout, $94, * 191$ transplantation and collagen disease, 287 bis

Kinins, urinary, excretion of, $* 491$

Knee effusion treated with gold salts, 493, *496

- osteo-arthritis of, tibial osteotomy in, 92

- , surgery of, *496

_., synovial fluid in, *488 bis

Kveim-Niekerson reaction in sarcoidosis, $* 581$

Lactic dehydrogenase level in serum as test of rheumatic carditis, 479

Larynx in rheumatoid arthritis, 90

Latex test, *197 bis

L.E.-cells, *488, 489

- in leprosy, 382

- phenomenon, 99

- inhibited by dexamethasone, *496

- in rheumatoid arthritis, 576

Leprosy, autoimmune mechanisms in, 382

Leucocyte studies, $* 490$ bis

-, synovial, 382

Los Angeles, acute rheumatism in, ${ }^{*} 282$

Lumbosciatica, *486, *487

Lung, fibrosis of, serology of, 383

in rheumatic fever, 576

_ , rheumatoid, $91,92,282,378,379,481$

tumour due to amyloidosis, *581

Lupus erythematosus, chronic, tissue antibodies in, 578

$\longrightarrow$, discoid, 288, 489

__
- - - neurological complications of, *193

$\ldots, \ldots$, organ antibodies in, 286

$\ldots \ldots$, in pregnancy, 191

eye lesions in, 487 bis

familial, 192

, immunopathology of, 192

in Negro, *487

photobiology of, 288

porphyria and, *487

, procainamide hydrochloride and, *193

serum factor, 380

, systemic, 98 ter, 99 bis, *289, *382

$-\longrightarrow$, systemic, 98 ter, 99 bis

$-\div,-$, cardiac conduction pathology in, $28 \mathrm{f}$

$\ldots, \ldots$, cyclophosphamide in, 494

$\ldots, \ldots$, eye changes in, 192

$-\ldots,-$ immunofluorescent studies of, 383, 5 -

__ _ _ _ and kidney transplantation, 287 bis

- - _ - laboratory studies of, 289

$\ldots,-$, myasthenia gravis and, $* 488$

- neurological and encephalographiça studies in, *294 *488

- _ - polyneuropathy and, 380

$-\ldots,-\ldots$, thymus abnormalities in, 286

, vascular changes in skin lesions of, 487

glomerulonephropathy, 381

nephritis, 287

- immunosuppressive therapy of, 494

Macroglobulin studies, 383

Madrid, rheumatic fever in, *480

Marfan's syndrome, 95 bis, 96 bis, 191, 485 bis

Mecholyl test, *103

Methanol metabolism inhibition, *490

Methytrienolone, action of, 493

Mikulicz's disease, 200

Morton's metatarsalgia, *581

Multifidus triangle syndrome, $* 380$

Muscle, central "core" disease of, 293

- fibres, antibodies against, 289

$\longrightarrow$, re-education of, 198

Myasthenia gravis and lupus erythematosus, $* 488$

$\longrightarrow$ and spondylitis, 379

Mycoplasmas (PPLO) in connective tissue disorders, $\overline{99}$

Myopathy, iatrogenic, *200, 385

Myositis, rheumatoid, *379

Neoplasm and collagen disease, $* 488$

Nephrolithiathis, urate, 484

Nephrosclerosis, rheumatic, 187

Nephrosis, amyloid, in rheumatoid arthritis, 92

Neurology of collagen disease, $* 294, * 488 \mathrm{ter}$

Neuropathy, peripheral, in rheumatoid arthritis, 91, $\$ 88$

Nodule, rheumatoid, of sclera, 282

Ochronosis, 485

Oestradiol, *491

Oestrogen therapy and cortisol metabolism, 290

Organ antibodies in disseminated lupus erythematosus, 286

Osseous tissue, metabolism of, ${ }^{*} 194$

Osteitis, haematogenous, 96

Osteo-arthritis, erosive, ${ }^{*} 482$ of foot, *283

_ of hip, *189 bis, *482 ter, 496, 577, *580 of knee, tibial osteotomy in, 92

Osteo-arthropathy, chromosomal abnormalities in, 577

Osteochondromatosis, *379 
Osteogenesis imperfecta tarda in four generations, 285

Osteomyelitis, spinal, 191

—, variolous, *97

Osteonecrosis of large joints, in rheumatoid arthritis, *481

Osteoporosis, *486 bis

- due to corticosteroids, $* 580$

-

heparin, 285

, idiopathic juvenile, 96

of rheumatoid arthritis, 378

Pain, low-back, 485, *486

- measurement of, ${ }^{*} 202$

Paramethasone, 386

Para-osteo-arthropathy, neurogenic, *581

Parapsoriasis, *483

Pentazocine, a new analgesic, 293

Periarteritis nodosa, eye changes in, 193 ter, 487

Periarthritis of hip, *486

$\longrightarrow$, scapulo-humeral, *191 bis

Periostitis deformans, 285

Pheniramine, *293

Phenylbutazone as cause of aplastic anaemia, 494 compared with indomethacin, 385

- , serum concentration of, 494

Phenylthiocarbamide test related to gastric acidity and taste perception, *294

Phlebography in osteo-arthritis of hip, 577

Plasma corticoids, 384 cortisol levels, 197

Pleurisy in rheumatoid arthritis, *189

Pneumonitis, rheumatic, 576

Polyarteritis nodosa, deafness in, ${ }^{*} 289$

- serology of, $* 290$

Polyarthritis, immunologic, in rat, *197 , infectious, steroid therapy of $* 580$

— in Kenya, 577

and sarcoidosis, 201, *294

Polymyalgia rheumatica, ${ }^{*} 488$ bis

and temporal arteritis, 381

Polymyositis, *202

Polynesia, gout in, 485

Polyneuritis and rheumatoid disease, *581

Polyneuropathy and systemic lupus, 380

Porphyria and lupus erythematosus, *487

Prednisone with aspirin and chloroquine, *580

Pregnancy, lupus erythematosus in, 191

Procainamide hydrochloride, 105, *193

Protein anabolism, 493

Psoriasis, *483, *488

and Reiter's syndrome, 284

Psychology of rheumatoid patients, ${ }^{*} 202, * 480,580$ of Still's disease, *379

Puerto Rica, rheumatic fever in, 187

Puromycin, inhibition of chondroitin sulphate synthesis by, ${ }^{*} 198$

Pyoarthrosis in staphylococcal septicaemia, *285

Radiology of acute rheumatism in children, *282

$\longrightarrow$ of arthritis, $188, * 189, * 283$

Radiotherapy of spondylitis, cancer after, 495

Rat, homologous disease in, as model for auto-immune disease in man, 579

Raynaud's phenomenon, 97, 98

Rehabilitation, muscular, 198

Reiter's syndrome, 93, 99, 482

- and psoriasis, 284

Resochin: see Chloroquine

Rheumatism, acute, 378

,$- \ldots$, activity tests of, $* 282$ bis $\longrightarrow,-$, in the adult, $* 282$

$\ldots, \ldots$, atlanto-axial dislocation in, $* 481$ bis

$\longrightarrow, \ldots$, and Behçet's disease, 90

__ _ _ - co-operative clinical trial of therapy of, 281

- - - epidemiology of, $281, * 480$ quater

,,-- glycoproteins in children with, $* 187$

$\longrightarrow,-$ indomethacin in, 377

,-- , intelligence and anxiety scores, *480

$\longrightarrow,-$, in Los Angeles, *282

$\ldots$ - natural history of, $187,281, * 480$

$\ldots$, - osteonecrosis of large joints in, *481

$\longrightarrow,-$, prophylaxis of, 377, $478 \mathrm{ter}$

—_, in Puerto Rico, 187

,-- , steroid therapy in, $281, * 282$

$\longrightarrow,-$ tonsils in, *480

$\longrightarrow,-$ urine studies in, *90

- classification of, $* 581$

_, palindromic, indomethacin in, 198

- post-anginal, $* 581$

Rheumatoid arthritis: see Arthritis, rheumatoid factor, $100, * 101$ bis, 196 bis, *197, *384, 489

— and myocardial infarction, 384

Rheumatology, international studies of, *386

Rhizomelic pseudo-polyarthritis, *189

Rice bodies from rheumatoid patients, 579

Rome, rheumatism in, *294

Sacro-lliac joint in ankylosing spondylitis, *189

Sacro-iliitis and ulcerative colitis, 93, 284

Salicylate concentration in blood, corticosteroids and, 495

- inhibition of cartilage degeneration, *195

- ototoxicity, 293

Sarcoidosis, 201

- and arthritis with syphilis, 294 bis

- Kveim-Niekerson reaction in, $* 581$

pleurisy, and lupus erythematosus, discoid, 381

-

Schönlein-Henoch syndrome, digestive manifestations of, *202

$-\ldots$, neurological signs of, $* 581$

Sciatic paralysis due to popliteal hydatid cyst, $* 487$

Sciatica, paradoxical, 380

Scleritis, necrogranulomatous, 282

Scleroderma, *289, 487, *488

- , generalized, 99

Sclerosis, progressive systemic, 288

, systemic, dextran infusions in, 492

Septicaemia, staphylococcal, with pyoarthrosis, *285

Serology of chronic rheumatism, 101, *102

of rheumatoid arthritis, 195 bis, $196 \mathrm{ter}, 197$ oct

Serotonin test, ${ }^{*} 101$

Serum albumin in rheumatoid arthritis, 481

- , iron-binding capacity of, $* 102$

- lactic dehydrogenase test of rheumatic carditis, 479

necrotizing factor, $* 290$

- protein electrophoresis, 195

Shoulder arthrodesis, *200

- bacterial arthritis of, 283

$\longrightarrow$, frozen, *191

- , rheumatoid arthritis of, $* 481$

Shwartzman phenomenon mechanism, 100

Sjögren's syndrome, 200, $201 \mathrm{ter},{ }^{*} 202, * 581 \mathrm{ter}$ and Hashimoto's disease, 580

Skin atrophy after corticosteroid injection, *200 lesions in Behçet's disease, *284

Spine, cervical, ageing of, $* 283$

$\longrightarrow,-$, radiology of arthritis of, $* 283$

$\ldots$, and rheumatoid arthritis, 92

- fracture, corticotherapy and, 494

Spondylitis, ankylosing, with arthritis of hip, ${ }^{*} 189$ 


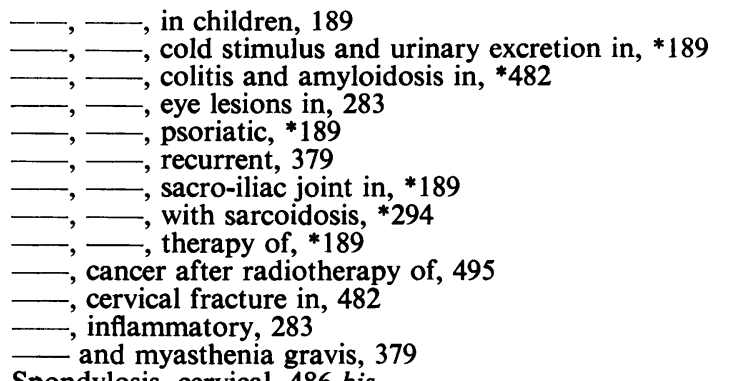

Spondylosis, cervical, 486 bis

Steroid hormone secretion in vivo, 491

therapy of acute rheumatism, $281, * 282$

- , arthropathy due to, $* 580$ 292 bis , eye lesions due to, 105 ter, 199 quater, 291 bis,

, immunology of, 289

_ of infectious polyarthritis, $* 580$

- massive prolonged, in rheumatic carditis in Filipinos, *580 , osteoporosis due to, $* 580$

withdrawal syndrome, 290

Still's disease, *379 bis, 481 bis, *482

—_ iridocyclitis in, 283

$\ldots$, radiology of, * $* 189$

—_ vegetative dystonia in, ${ }^{*} 189$

Streptococcal antibodies, experimental, *490 bis

Streptococcus infection in rheumatic fever, $* 480$ bis

Stress, corticosteroid therapy and, 385

Surgery of arthritis, *379

Sydenham's chorea, treatment of, 90

Synovectomy of wrist, 495

Synovial fluid, haptoglobin in, 194

joints, biomechanics of, *195

Synovium histamine content of, ${ }^{*} 103$
-

studies of, 382 bis, *488 bis

Syphilis and arthritis with sarcoidosis, 294

Talalgia, *581

Taste perception in rheumatoid arthritis, $* 282, * 294$

Tendinitis, nodose, in rheumatoid hand, ${ }^{*} 200$

Tenotomy in surgery of osteo-arthritis of hip, *189

Therapy, current trends in, ${ }^{*} 200$

Thiotepa and synovial fluid, 382

Throat, serology and bacteriology of, before and afer tonsillectomy, $* 580$

Thymus abnormalities in systemic lupus erythematoşls and myasthenia gravis, 286

Thyroiditis, chronic, Sjögren's syndrome and, 201 Hashimoto's, 91, *283, 378

Tonsils in rheumatic fever, $* 480$

Traction, vertebral, $* 200$

Ulcer, leg, in rheumatoid arthritis, 92

Ultra sound therapy, *200

Uricosuria in gout, ${ }^{*} 191$

Urine studies, *491 sext

Uveitis, 483

— and ulcerative colitis, 93

Vasculitis in rheumatoid arthritis, 480

Vasopressin and ACTH secretion, 290

Virus studies in rheumatoid arthritis, *491

Warsaw, rheumatic fever in, $* 480$

Weber-Christian disease, $* 581$

Whipple's disease, $189,190, * 285$

Wrist, intrasynovial hydrocortisone in, *496

- , synovectomy of, in rheumatoid arthritis, 495

19S antibody production, 195 


\title{
INDEX TO AUTHORS OF ARTICLES ABSTRACTED
}

\author{
* indicates that only the title is given
}

Aarskog, D., 102

Abbas, A. S., *480

Abgrall, G., 577

Acheson, R. M., 281

Adatto, I. J., *282

Agarwal, R. C., 105

Agarwal, R. P., 494

Ahlman, K., 282

Aho, K., 282, *384

Ahuja, O. P., 95

Aikat, B. J., 487

Aixala, R. A., ${ }^{*} 480$

Aixala, R. A., *480
Alarcón-Segovia, D., 98, 99, Benditt, E. P., 102 188

Albrecht, M., 579

Alepa, F. P., 201

Allen, D. J., *384

Almeyda, M., *200

Altchek, M., 495

Amatruda, T. T., Jr., 290

Beck, E. R., 98

Beck, J. S., 201, 487

Becker, H., 485

Becker, L. de, 106

Beetham, W. P., Jr., 194

Beickert, A., 287

Belau, P. G., 201

Belinsky, A., 191

Benazet, J., 378

Bencze, G., 197, *294

Bender, L. F., 188

Bennett, M. J., *581

Berche, L., 487

Berman, L., *200

Bernier, J.-J., 282

Bernstein, D., 93

Bernstein, J. M., 293

Bertram, U., 286

American Heart Association, Bertrand, J.-N., *285 187, 281

Amor, B., *491, *581

Andelman, S. Y., 199

Andreis, M., *200

Anholt, L. M., 201

Antopol, W., 100

Arlet, J., *202, 378

Artiùcha, Z., *581

Asher, J. D., 285

Astorga, G., 382

Atdjian, M., 105, 292

Audran, R., *101

Aufdermaur, M., *189

Aurel, M., *200, 385

Bäckdahl, M., *200

Baculard, A., *480

Baer, R. L., 288

Baggenstoss, A., 99

Bajan, A., *581

Baker, D. T., 480

Balagot, R. C., 293

Balcar-Borón, A., ${ }^{*} 187$

Bansal, N. C., 495

Barceló, P., *194

Bardadid, T., *581

Bardenheier, J. A., *490

Barefoot, S. W., 482

Barnett, E. V., 196

Barrows, H. S., *488

Bartholomew, L., 99 bis

Bassøe, H. H., 102

Baur, M., 580

Baylor, R. A., *95

Beach, V. L., *103

Bec, K., 495
Biaria, C., 489

Biav, C., 495

Biclesanu, A., *282

Bielecky, T., 577

Billiar, R. B., 490

Binder, H. J., *481

Birnstingl, M., 97

Blade, J., 193

Bland, J. H., *283

Blau, S., *195

Bloch, B., *488

Bloch, K. J., 201

Bloch-Michel, H., 189

Block, M. A., 97

Rlumencron, W., 103

Boardman, P. L., 385

Boccardi, V., *490

Bochu, M., *293

Bodel, P. T., *490

Böhni, P., *188

Bollet, A. J., 95, 382

Bonamour, G., 483

Bondar, B., 105

Böni, A., *'189

Bonnet, M., 483

Bonomo, L., 382

Bonte, J., *581

Borrachero, J., *191

Bosajieva, E., 577

Bourgeois, P., *290

Boursiquot, P., *486

Boutin, C., 494

Bouvier, M., *285

Bowie, M. A., 102

Brattström, M., 481 bis

Braun, H., *191
Braun, S., *200, 385, *581

Braun-Falco, O., *289

Breckenridge, A., 484

Breckenridge, R. T., *485

Brégeat, P., 106

Brémová, A *282,*294 *481 Cobb, S., *202, 580

Bretagne, A., 495

Brewer, E. J., Jr., *379

Britto, A., *486

Brizard, J.. 189

Brocteur, J., *200

Brooks, F. P., 197

Brousse, J. P., *581

Brown, E., *283

Brown, L. N., 201

Bruckner, F. E., 198

Bruetsch, W. L., 187

Brun, C., 480 $* 283$

Bugallo Paz, L. M., *483

Bunim, J. J., 201

Burch, P. R. J., 577

Burnet, F. M., 289

Burnham, T. K., *490

Butler, I., 106

Cain, J. C., 99

Calmettes, L., 495

Cameron, E. A., 494

Camus, J.-P., 379, *485

Caravano, R., *480

Carlsen, B. H., *289

Carneiro, R. A., *490

Caron, J. P., *487

Carpenter, R. R., *382

Carter, J. B., 379

Cary, G. R., *488

Castaing, R., *189

Cathcart, E. S., ${ }^{*} 102$

Catterall, M., 97

Cebecauer, L., 194

Centeno, E., 100

Cesari, M., *285

Chapman, S. S., *480

Charpin, J., 494

Chávez, S. A., *200

Chen, E., *202, 580

Cheng Siang, S., 494

Chevallier, J., *581

Chew, A. G. K., 494

Christenfeld, R., *202, 580

Chrisman, O. D., *195

Christian, C. L., *384

Christopher, R. P., 188

Chryssanthou, C., 100
Cifarelli, P. S., *518

Ciocci, A., ${ }^{*} 293$

Čizova, Z. A. 192

Claessens, H., *581

Cobb, S., *202, 580
Coburn, A. F., ${ }^{* 480}$

Cockshott, W. P., *97

Cohen, C., *285

Coibanu, V., *490

Collum, T. B., *95

Condemi, J. J., 196

Cone, A. L., *480

Consigli, V. P., *294

Cooper, G. A., *483

Cooper, J., *480

Cordier, J., 495

Correa T, E., 377

Coste, F., *200, 385, *386, *491, *581

Coulonjou, R., 577

Couris, G. D., 97

Court Brown, W. M., 495

Coventry, M. B., 92, 93, 283

Cox, J. B., 191

Crabbe, W. A., *283

Cremer, G., 198

Crews, S. J., 199

Crompton, M. R., *293

Cross, R. M., 193, 194

Crozier, J. A., *290

Cucu-Cabadaief, L., *282

Cummings, N. F., *488

Curtarelli, G., 386

Czarnecki, S. W., 105

Daguet, G.-L., *197, 384

Dale, A. J. D., 106

Dalous, A., *202

Dammacco, F., 382

Danielsen, L., *102

Dannheim, R., 105

Darke, C. S., 90

Darleguy, P., 193

Dash, M., 198

David-Chausse, J., *189

Davidsohn, I., 489

Davidson, F., 485

Davis, J. E., 380

Davison, S., *488

Debeyre, N., 576

Degoy, A., *202

Delahaye, R. P., *486

Delbarre, F., *200, 385, *386, $* 491$ 
del Carmen Sánchez, M., *191 Ferriman, D., 385

del Giaco, G. S., *102

Delogu, A., 106

Denis, A., 198

Denko, C. W., *202

Dent, C. E., 96

Deodati, F., 495

Deshayes, P., *294

de Silva, P., *581

Desnos, J., *581

D'Esopo, N. D., 290

Desseauve, J., *294

Devlin, H. B., *486

Dick-Smith, J. B., *580

Dickson, J. A., 92

Diederich Sen, H., *193

Diessner, G. R., 379

Dietze, H. J., *488

Dillaha, C. J., 288

Dingle, J. H., *101

Dingwall-Fordyce, 1, 580

Dipasquale, G., *103

Dito, W. R., 378

Dobrota, S., *581

Dodge, H. J., 190

Doll, R., 495

Dorlencourt, M., 106

Dornetzhuber, V., *581

Dorsey, C. S., *488

Drenick, E. J., 484

Drouin, R., *496

Dry, J., *283, 577

Dube, J., *496

Duchowska, H., *480

Dugan, A., 102

Dugast, P., *581

Dunaeva, E. M., 486

Duncan, H., 378

Durant, J., 92, *581

Dybkaer, R., 189

Dyken, M., 284

Dykman, C. J., 187

Dyrud, O. K., *491

Egiozarova, S. V., 192

Eichler, K., 483

Eidelman, S., 190

Eik-Nes, K. B., 490, 491

Einerth, Y., *384

Eisen, A. A., 494

Elderkin, F. M., 96

Elling, P., 100

Endres, M. A., *486

Engh, G., 95

Epstein, W. V., 100

Eriksen, N., 102

Espiner, E. A., 291

Evangelista, I., 293

Evans, J. H., 486

Eyquem, A., 101

Faber, V., 100

Farrell, F. J., 201

Faulong, L., *487

Feltkamp, T. E. W., 289

Feltkampvroom, T. M., 289

Fernández del Vallado, $\mathbf{P}$ *191

Ferrandis, R. Moleres, *483, $* 581$

Fine, B. S., 292

Frank, P. F., 377
Feuerman, E. J., *483

Fine, G., *490

Finelli, P., 106

Finlayson, N. B., 197

Fiore, L., *379

Firestone, F. N., *581

Flanagan, B., 285

Flanagan, P., 193

Fontignie, J., *189

Forconi, S., 95

Ford, J., 289

Forsham, P. H., 290

Fostiropolous, G., 293

Fournier, A., 495

Fraga, A., 192

François, J., 106, 292

François, P., 487

Françon, F., *189

Françon, M. J., *580

Frandsen, E., 291

Frawley, T. F., *491

Freimer, E. H., 378

Frenger, W., 190

Fresse, B., *380

Frey, H.-H., 494

Friedman, J. J., 99

Friedman, M., 96

Fronzaroli, L., *197

Frost, H. M., 378

Gaipa, M., 106

Galews, G. J., 187

Galmiche, P., 282

Gamp, A., 192

Ganzoni, A., *188

Garcia, H. C., *580

García Soro, J. M., *191

Gardiner, *491

Garrido, M., *483

Gatter, R. A., *202

Gaucher, A., *380

Gaudin, M., 282

Gavrilova, K. M., 488

Gburek, Z., *191

Geffroy, Y., *294

Geniaux, M., *189

Gennari, C., 95

Gerbeaux, C., *480

Gerbeaux, J., *480

Gijón Baños, J., *191

Giles, C. L., 200

Gill, D., *496

Ginsberg, V., 489

Gleason, I. O., 94

Gliniecki, G., *491

Golay, M., 381

Goldberg, R., 101

Goldfinger, S. E., 94

Golding, D. N., 198

Goldman, M., *486

Goldstein, G., 286

Gomez, R.-A., *580

Gomez Carpio, M., *200

Gonatas, N. K., 293

Gonçalves, G. W., *496

Gonçalvez, N., 191

Gonick, H. C., 94
Good, A. E., 187, 188

Goodman, J. S., 187, *480

Gospodinoff, A., *379

Gospodinoff, L., *379, *481

Gottlieb, A. A., 577

Gottlieb, A. J., 383

Goullet, P., *197, 384

Granstrand, B., *491

Grant, I. W. B., 379

Grant, S. D., 290

Grasso, A., *490

Greenhouse, A. H., *488

Griffith, G. C., 285

Grimaldi, M. G., *290

Grimble, A., 195

Grossman, *480

Gruber, J., *490

Grupper, C., 106

Gruson, M., *486

Grzybowska, J., *480

Guasch L, J., 377

Guerra, U., *480

Guilbert, 487

Guillerez, F., 487

Guinot, R., *581

Gutman, A. B., *285, 483

Gutowska-Grzegorczy, G., *480

Gwon, N. W., 386

Gynning, I., 493

Haba, G. de la, *198

Halberg, P., 286, 378

Halberstam, D., 93

Hall, L., 577

Hall, P. H., 491

Hallen, L. G., *496

Halmi, O., 192

Hamerman, D., *195

Hames, C. G., 195

Hána, I., 283

Hancock, J. A. H., 482

Händel, D., *187

Hanshoff, G., *491

Harber, L. C., 288

Harden, R. McG., 91

Harris, F., 93

Harris, M. Y., *487

Hart, F. Dudley, 385

Hartman, J. T., 92

Hartwig, W., 200

Harvey, H. P. B., 485

Harville, W. E., 91

Haserick, J. R., 287

Hashiguchi, T., *102

Hashmi, J. A., *480

Hassan, *490

Hathaway, B. E., 577

Havre, D. C., 105

Hawkins, C. F., 104

Hedner, P., *384

Heijer, A., *581

Henkind, P., 105

Henney, C. S., 196

Herschler, R. J., 103

Hidalgo, J. U., 481

Hilf, R., 490

Hillderdal, O., 294

Hiltz, J. W., 106

Hioco, D., *486
Hirose, S.-I., 196

Hoffbrand, B. I., 98

Holland, N. H., 494

Hollander, J. L., 197

Hollingsworth, J. W., *481, *490

Holmes, M. C., 289

Holp, L. P. J., 104

Holti, G., 492

Holtzer, H., *198

Honeycutt, W. M., 288

Horan, A., 290

Horning, *491

Horowitz, I., 482

Horwitz, M., 99

Houli, J., *285, *580, *581-

Howard, F. M., Jr., 379

Howell, D. S., 483

Howes, R. G., 382

Hubert, J., *294

Hueston, J. T., 496

Hurst, M. M., 290

Husmann, F., 104

Irby, R., 287

Irgang, S., *487

Isémein, L., 190

Iuel, J., *200

Ivankovic, I., 580

Jackson, D. C., 288

Jackson, W. P.' U., 93

Jacob, K. O., *191

Jacob, S. W., 103

Jacobs, P., *189

Jacox, R. F., 196, 579

Jacqueline, F., 101

Jakubowska, K., *581

James, T. N., 287

James, V. H. T., 385

Janis, R., *195

Jansen, T. G., 288

Janukowicz-Lorenz, H.,

Jarvis, B., 382

Jarzebska, D., *480

Jayaratnam, F. J., 494

Jeanblanc, J., *380

Jensen, K. B., *491

Jeremy, R., 197

Ježková, 577

Jick, H., 492

Johnson, G. D., 197

Johnston, E. N. M., 97

Joison, J., *581

Jones, F. R., 193

Jones, J. D., 201

Juge, P., 106

Julkunen, H., 192

Junod, A., 381

Jurckova, T. G., 192

Jutila, J. W., *198

Kaganas, G., *496

Kahn, M. F., *488, 576

Kalczak, M., *480

Kalliomäki, J. L., *200

Kampmann, E., 494

Kan, D. V., 191

Kanie, R., *382

Kaplan, A., 577 
Kaplan, D., 93

Kaplan, J. M., 105

Kaplan, S., 90

Karakawa, W. W., *490 bis

Karl, H. J., 197

Karr, J., 490

Kashiwagi, K., *103

Kasl, S. V., *202, 580

Katona, G., *200

Katzenellenbogen, I., *483

Kellermeyer, R. W., *485

Kellett, D. N., *496

Kelly, P. J., 283

Kemp Harper, R. A., 288

Kennedy, C. B., 480

Kessler, I., 576

Khan, A. H., *480

Kidd, *482

Kienle, G., *380

Kirk, J., 92

Kitay, *491

Kitlak, W., *187

Kleine, F. D., 285

Kleinfelder, H., 104

Klemm, G., 285

Klenka, L., 283

Kliman, B., 291

Klinenberg, J. R., 94, 495

Knodt, H., *482

Koepke, G. H., 188

Koffler, D., 383

Kogstad, O. G., 381

Kolb, H., 292

Kolečkáčová, M., 283

Kolker, I. S., *197

Kostia, J., *379

Kubicka, K., *480

Kunitake, G. M., 289

Kunkel, H. G., 577

Kurljukova, I. M., 192

Kuttner, A. G., 281

Králová, M., *481

Kravitz H. M.,

Kretschy, A., *200

Kryger, J., *200

Laaban, J., *486

Laaksonen, A.-L., *189

Labeille, J., *581

Lacapère, J., *197

Lacaze-Masmonteil, J., *486

Lachance, P., *496

Lachhein, L., 285

Lackland, H., *490

Lacoste, B., *189

Lakatos, L., *294

Lange, K., 98

Lanham, C., *486

Lapa, W., *486

Latta, H., 381

Laurén, P. A., *200

Lavarde, G., 380

Lawrence, J. S., 580

Layton, D. D., 106

Lazowska, S., *581

Lee, C. L., 489

Lee, S. L., 386, 489

Legier, J. F., 576
Lejeune, E., *285

Lemercier, J.-P., *294

Leonards, J. R., 103

LeRoy, E. C., 579

Leskiewicz, W., *480

Lessof, M. H., 195

Levernieux, J., 198

Levickaja, S. V., 192

Levin, W. C., *487

Levine, J. I., *480

Levy, G., 103

Lewenfisz-Wojnarowska, $* 480$

Lewis, D. C., 380

Li, C. C., 92

Liberati, E., *197

Librik, L., 290

Licht, E., *480

Lichtman, M. A., 19

Limouzy, P., *202

Lindahl, O., *496

Linder, L., 294

Lindquist, B., *496

Linn, F. C., *103

Linscheid, R. L., *195

Lipscomb, P. R., 495

Litman, N., 381

Litwin, S. D., *101

Livanou, T., 385

Lloyd, A. G., 194

Lloyd, L. A., 106

Lobomudrov, F. E., 193

Loni, C., *197

Lorenzen, I., 288

Louyot, P., *380

Luccioni, R., 494

Lucherini, T., *189, *580, *581 bis

Ludwig, K., 192

Luez, J., 487

Lumsden, K., 93

Lund, H. Z., 482

Luntz, M. H., 93

Lurie, M. B., 289

McAdams, A. J., 494

McCarthy, M., 378

McCarty, D. J., Jr., *202

McCollum, D. E., 485

McConville, J. M., 494

McCormack, L. J., 287

McCracken, A. W., 193

McDonough, J. R., 195

McDuffie, F. C., 489

Macgregor, J., *486

Mackay, I. R., 286

Mackenzie, A. H., 105, 292

McTigue, J. W., 292

Madrid, J., *191

Magsaysay, R., 289

Maîtrepierre, J., 92

Makarenko, I. I., *481

Malahovskic, J. E., 192

Malawista, S. E., 95, 577

Malbrán, J., 292

Maldyk, E., *480, *482

Malina, L., 577

Manschot, W. A., 99

Mantovanelli, S., *282
Marinetti, G. V., 579

Marmalzat, W. L., *488

Marmor, L., 104, *496

Marshall, C. M., 188

Marshall, T. R., *581

Martin, E., *290

Martin, W. J., 93, 283

Martre, P.-H., *189

Masanti, J., 191

Mason, P., *488

Massumi, R. A., 576

T., Mastella, G., *282

Mathur, K. N., 485

Matsafey, G. V., 193

Matson, C. F., *95

Matte, C., ${ }^{*} 101$

Mattenheimer, H., *191

Mattocks, A. M., *384

Matuszewski, J., *480

Maudgal, M. C., 292

Maxfield, W. S., 481

Mayne, J. G., 284

Mazzei, D., *102

Medical Research Council 187,281

Meer, P. van der, *92

Megahed, G. E., 479

Mégard, M., 92

Mejbaum-Katzenellenbogen, W., ${ }^{*} 187$

Melander, B., *491

Mella, B., 283

Merola, G., *481, *482

Merriam, L. R., *490

Messias, A. R., *486

Meyer, K. H. zum B., 192

Michalowicz, R., *581

Mikkelsen, W. M., 190

Milgrom, F., 100, *197

Miller, *580

Miller, F., 495

Miller, L. F., 377

Miller, S. J. H., 199

Milosovich, G., *384

Mills, G. C., *487

Milunicová, A., *294

Mintz, G., 192

Moens, C., *200 bis, *491

Moffitt, G. R., Jr., 287

Mohajenin, A. H., *483

Mole, J., 378

Molyneux, M. K., 580

Montgomery, M. M., *282

Monto, R. W., 287

Monz, W., 96

Morgan, H. C., *490

Mortimer, E. A., Jr., 377

Moskowitz, R. W., *290

Mossiconacci, P., *480

Moullec, J., *101

Muench, H., 492

Mullinax, F., 287

Munk, J., *282

Murison, P. J., 481

Murray, R. O., 482

Myers, E. N., 293

Nakamoto, S., 287

Nakamura, R. M., 289

Nazzaro, P., *284
Neblett, T. R., *490

Neligan, G. A., 96

Nema, H. V., 495

Nerup, J., 286

Newbould, B. B., 101

Nichols, G., Jr., 285

Niedermeier, W., 194

Niranjan, L. M., 494

Nishi, I., 489

Nishizawa, E. E., 490

Nordby, G. L., *488

Nordin, B. E. C., *486

Nørgaard, F., 188

North, A. F., Jr., 196

Nousek, J. E., 105, 292

O'Brien, W. M., 92, *481

Odelberg-Johnson, O., 493

Odom, G. L., 485

Ognibene, A. J., 378

Ohanian, S. H., 382

Ohresser, P., 494

Oikawa, T., 489

Olsen, T. S., 480

Opie, L. H., 105

Opie, W. H., 105

O'Quinn, S. E., 480

Ores, R., 98

Orlov, G. A., 488

Ortbauer, R., 105

Osler, A. G., 196

Osmundson, P. J., 98

Ostrowski, Z. L., *581

O'Sullivan, J. B., *102

Ottaviani, C., 96

Pahwa, J. M., 494

Paine, R., *193

Pal, S. B., 491 bis

Pallis, C. A., 91

Paluska, E., *102

Panja, R. K., 487

Papahagi-Dumitresco, E., 105

Papilian-Stoichita, M., *490

Paquet, C., *496

Parkhill, E. M., 106

Paronetto, F., 383

Parrochia, B. E., ${ }^{* 202}$

Parson, W., 95

Patri, A., 377

Patterson, C. P., 91

Patti, A. A., *491

Paufique, L., *485

Pavlaggi, F., 577

Pavlatos, F. C., 290

Peitersen, E., *289

Pelkonen, R., 192

Pellet, A. C., *496

Peltonen, T., *189

Péquinot, E., 493

Percy, J. S., 491

Peregrin, J., 292

Perel'man, V. M., 191

Perez, M. C., 293

Perissel, J., *200

Perkins, E. S., 199, 483

Perrignon, M., 286

Perry, H. O., 284

Persellin, R. H., *491 
Peter, ${ }^{*} 482$

Petrov, B., 577

Petty, T. L., 481

Peylan, A., *386

Phelps, P., 190, *202

Phillips, R. S., 577

Piacentini, G., *488

Pierce, J. A., 91

Pietilä, J., 578

Pietschmann, H., *200

Pilz, C. G., *282

Pinals, R. S., 492

Piquet, B., *379

Pirvu, V., *490

Pitkänen, E., 192

Plotz, C. M., 101, *488

Press, P., 381

Prichard, R. W., 380

Prior, I. A. M., 485

Prokopová-Roubalova, D., *194

Propp, R. P., *282

Podliachouk, L., 101

Pollack, V. E., * 191

Polyakova, G. P., *580

Pongor, Z., 192

Porzio, F., *189

Poske, R. M., *282

Pouget, J. M., *282

Pugh, D. G., 201

Pyzikowska, J., *581

Quinton, A., *189

Raaschou, F., 480

Raith, L., 197

Rajka, G., *496

Rambaud, G., *293

Rambaud, J.-C., 282

Randle, A. P. H., 198

Rapado Errazti, A., *191

Raunio, P., 576

Ravault, P.-P., *285

Ravenni, G., 95

Raymond, F. D., 102

Reed, N. D., *198

Reed, W. B., *581

Reeves, J. A., 487

Reid, A., *202

Reinhart, R. A., *480

Reitman, E. E., *379

Remolar, J. M., 201

Renard, G., 578

Renault, P., 92

Reny, A., 495

Resio, J., 191

Restifo, *580

Rezek, J., *285

Ricca, L. R., 483

Riera, A., *202

Rigby, B. J., *488

Rinvik, S. F., *491

Riu, R., 193

Roberts, R. H., 201

Robinson, B. V., *490

Robinson, H. S., *481

Robinson, R. D., *480

Robles Gil, J., *200

Robson, J. M., *490

Roenigk, H. H., Jr., 287
Rogé, J., *290

Rogers, D. R., 102

Roisenblit, A., 201

Roitt, I. M., 195

Romicka, A., *480

Rose, B. S., 485

Rosen, P. S., 93

Rosenbaum, E. E., 103

Rosenberg, M. A., 482

Rosenberger, A., *282

Rosomoff, *486

Rossmann, *486

Rostawski, A., *189

Rouby, M., 190

Rowell, N. R., 97, 487

Roztropowicz-Denisiewicz, K., *482

Rubegni, M., 95

Rubin, C. E., 190

Rubini, M. E., 94

Rudowski, W., 200

Ruitton, P., *285

Rupe, C. E., 97, 287

Ryckewaert, A., *283, *486, 576, 577

Sabiston, D. W., 106

Sadove, M. S., 293

Salanova, J., *202

Salavec, M., 292

Salomon, A., 189

Salowska, M., *581

Salqueiro, M., *483

Salzman, R. T., 483

Sampson, J. J., 105

Samuel, J., 198

Sander, C., *384

Sandson, J., * 195 .

Santos, O. de Rosa, *580

Saratchew, T. M., *283

Sato, M., *102

Saudax, E., 495

Saxen, E., 192

Saxena, R. B. 485

Sbarbaro. J. L., Jr., 199

Scalabrino, R., *290, 386

Schakir, R., 282

Scherbel, A. L., 105, 292

Scherago, M., *490

Schiavetti, L., *482

Schierz, G., *384

Schilling, F., 192

Schirmer, A., *189

Schmitt, A., *380

Schoenfeld, L. S., 100

Schuffner, N. O., *581

Schultz, F., 489

Schultz, R. T., *197

Schuster C, A., 377

Schwab, J. H., 382

Scoggins, R. B., 291

Scott, J. T., 91

Secondo, G., *101

Seda, H., *283

Seegmiller, J. E., 94, 95, 577

Segrestaa, J. M., 92

Seidel, K., *282

Semb, C., 496

Sengupta, K. P., 487

Serre, H., *481
Sevel, D., 93, 282

Sèze, M. de, *283

Streda, A., *481

Strom, T., *488

Sèze, S. de, 198, *283, *486, Strouth, J. C., 284 576

Shatin, R., *481

Strzelecka, M., *480

Sturgill, B. C., *382

Shefferman, M. M., 187, *480 Suárez, V. E., *191

Shichikawa, K., *581

Shukala, B. R., 95

Shulman, S., 100

Shy, G. M., 293

Sibayama, Y., *90

Sicard, A., 380

Siddiqui, M. K., *480

Siegel, M., 386, 489

Siemienska-Rywik, S., *480

Siering, H., *282

Sievers, K., *197, 282

Sigler, J. W., 378

Siltzbach, L. E., 383

Similä, S., 578

Simmons, D. P., * 195

Simon, L., *481

Singer, J. M., 101 bis

Siurala, M., 192

Sivuha, T. A., 486

Skalba, D., 489

Skladniova, V. M., 193

Sliwowska, W., *581

Slone, D., 492

Slotwinska, L., *480

Smiley, W. K., *283

Smith, D. A., *486

Smith, F. G., Jr., 381

Smith, J. B., 380

Smith, V. K., 491

Smyth, C. J., 492

Søborg, M., 286

Solignac, H., *487

Sokoloff, L., * 103, 201, 577

Somló, Z., *294

Sommers, S. C., 94

Somogyi, I., *294

Sorem, G. L., 579

Soren, A., *200

Sørensen, A. W. S., 480

Soriano, M., 285

Spencer, R. W., 199

Spiera, H., 383, *488

Spiers, F., 291, 292

Spiro, H. M., *481

Stack, B. H. R., 379

Stamp, W. G., *490

Stanworth, D. R., 196

Stastny, P., 579

Steffen, C. * 384

Stein, A. A., *491

Steinbeck, A. W., 198

Steinberg, A. G., 201

Steinbuch, M., *101

Steinetz, B. G., *103

Stembridge, V.' A., 579

Stenman, U.-H., *379

Stepán, J., *102, *282, *294

Stern, A., *282

Stickler, G. B., 201

Støa, K. F., 102

Stoia, I., *487

Stollerman, G. H., 377

Strandberg, O., *200

Strauss, W., 98

Trnavsky, K., 194
Sugiyama, T., *103

Sultana, S., *480

Summerly, R., 97

Sundberg, J., 481 bis

Sussman, L., 290

Susta, A., *282

Svartz, N., 383, 384

Svec, K. H., *101

Svěrák, J., 292

Syed, S. A., *480

Szymanska-Jagiello, W., *480

Szymanski, A., *580

Tabau, R.-L., 190

Takahashi, T., 489

Talbott, J. H., *485

Taleisnik, J., *195

Tamler, E., *200

Tampas, J. P., *283

Tan, E. M., 578

Tarnopolsky, S., *491

Tarter, M. E., 188

Taylor, F. H., 92

Teare, R. D., *293

Teican-Gheorghiu, M., *490

Tellier, M., 198

Tempska, K., *581

Terres, G., 579

Tesárek, B., *194

Tessier, R., *189

Texier, A., 191

Thebault. J., 578

Theile, H., 198

Thompson, G. R., *379

Thompson, M., 491

Thompson, R. A., 384

Thorsen, T., 102

Tierney, R. C., 90

Tierstein, A. S., 383

Timpl, R., *384

Tirlea, J., *282

Toivonen, S., 192

Toone, E. C., Jr., 287

Torrigiani, G., 195

Trémolières, J., 493

Trier, J. S., 190

Trimigliozzi, G., 382

Trimm, A., 486

Trnavská, Z., 194

Truelove, S. C., 93

Tuffanelli, D. L., *488

Tuzi, T., *485

Tzoneva-Maneva, M. T., 5 J్

Udenfriend, S., 578

Ullian, R., 492

Ultan, L. B., 187

Vagač, M., *581

Vainier, C., *487

Vainio, K., *379, 576

Vaisman B, M. S., 377

Valdes, J., 187

Valenzuela, J. M., 292 
Valkenburg, H., 190

Van Buskirk, F. W., *283

VanderVelde, E., *581

Vänttinen, E., 488

Vaughan, J. H., 196, 579

Vecchio, C., *102

Vecchione, L., 106

Verjans, H., *200

Viara, M., *101

Videbaek, A., 288

Vidon, N., 282

Vieira, H. P., *486

Vignau I, A., 377

Vignon, G., 92, *285, *581

Viljanto, J., 488

Villanneva, A. R., 378

Vischer, T., 579

Vladesco, C., *490

Vodniova, R. E., 193

Voegele, G. E., ${ }^{*} 488$

Vojtisek, O., *102
Völker, R., 483

Volle, L., *285

Vovan, L., 190

Wachstein, M., 98

Wachtel, H. L., 105

Walder, D. N., 98

Waldeskog, B., 493

Wallace, S. L., 93

Waller, M., 287

Walser, A., 580

Wannebrouco, C. P., 487

Ward, L. E., 188, 201

*295, Wasz-Höckert, O., *379

Watkinson, G., 283, 284

Weaver, J. P. A., 98

Weiss, T. E., 481

Wellinger, C., *581

Wells, J., *189

Wendeberg, B., 493

Wertlake, P., 201

Wesolowska, H., *480
West, C. D., 494

Widelock, D., 386

Wiklander, O., *384

Wilkins, M., 481

Wilkinson, M., 92

Wilkinson, P., 197

Wilkoszewski, E., *480, *482 Zabokrzycki, J., *581

Winer, J., *581

Wing, H., *581

Witebsky, E., 100

Witkowski, R., 285

Wójcik, T., *480

Wolff, S. M., *488, 579

Wolf-Jürgensen, P., 378

Wollensak, J., 190

Wolman, L., 90

Wong, K. H., 494

Wong, W., 489

Wright, R., 93

Wright, V., 283, 284

Wróblewska, T., *581

Wrzyszcz, M., *189
Yassin, A. M., 479

Yigitbasi, Ö., 90

Yenice, O., 90

Young, A., 90

Yü, T. F., 483

Zachariae, E., *103, *580

Zachariae, H., *103

Zachariae, L., 291

Zaino, E. C., *581

Zampetti, A., *294

Zangara, A., *290

Zawadzki, Z. A., *482

Ziff, M., *491, 579

Zilli, E., *480

Zimmerman, L. E., 292

Zolotariova, M. M., 193

Zoppini, A., *490

Zucchelli, G. P., *285

Zuniga, V. L., *483

Zwaifler, A. J., *379 


\section{INDEX TO SYMPOSIUM ON ALLOPURINOL SUPPLEMENT TO VOLUME 25, NOVEMBER, 1966}

*indicates a contribution to a Discussion

Abrahams, O. L.: see Levin, N. W., etc., 681

Acid, uric, ${ }^{14} \mathrm{C}$ labelled,* 621, 653

Adenine, 602

Allantoin, 602

Allo-xanthine (DHPP), 602, 609, 615, 685

AMOR, B.: see Delbarre, F., etc., 627, *706

AusCHER, C.: see Delbarre, F., etc., 627

Azotaemia, 675

BALIS, M. E.: see Krakoff, I. H., etc., 651

BERGEL, F., *648, *667 bis

Bibliography, 710

Biochemistry, 601, 608, 615, 668

Blood disease, 657, 668, 675

BRECKENRIDGE, A., *667

Contributors, alphabetical list of names and addresses, 717

Delbarre, F., Amor, Auscher, C., and Gery, A. De: Treatment of gout with allopurinol, 627, $* 705$

Duthie, J. J. R., *646

Elion, G. B.: Enzymatic and metabolic studies with allopurinol, 608, *622 bis, *648, *649, *667

EMmerson, B. T.: Effects of allopurinol on iron metabolism in man, $700, * 622,{ }^{*} 648$

Enzyme studies, 608

Frank, M.: see Vries, A. de, etc., 691

Frazier, P. D.: see Seegmiller, J. E., etc., 668

GERY, A. DE: see Delbarre, F., etc., 627

Glover, R. P.: see Kuzell, W. C., etc., 634

GLYN, J. H., *650, *707

Gout, acute attacks of, *646

-, "corticoid-dependent", *647

688,694

$\longrightarrow$, renal complications of, $668,681,688,691, * 706$

GraHAME, R., *645 ter

Guanine, 602

HaLl, L., *645

Hitchings, G. H.: Effects of allopurinol in relation to purine biosynthesis, $601, * 622$ ter, $* 647,{ }^{*} 650$

Hood, D. B., *646, *706

Houpt, J. B.: see Ögryzlo, M. A., etc., 673

Hypertension, 661

Hyperuricaemia, primary, 623, 627, 634, 643

and psoriasis, $* 647$

—, secondary, $651,655,657$

, thiazide-induced, 660

Hypoxanthine, 602

Iron metabolism, 697, 700, *704

JACxman, A.: see Kuzell, W. C., etc., 634

Kerr, D. N. S., *621, *667, *704

KERSLEY, G. D.: Allopurinol in primary gout with and after uricosuric agents, $643, * 647$

Kidney studies, 673, 668, 681, 688, 691, 694, *706

Krakoff, I. H., and Balis, M. E.: Allopurinol in the prevention of hyperuricaemia secondary to the treatment of neoplastic diseases with alkylating agents, adrenal steroids, and radiation therapy, $651, * 645, * 667$ ter, $* 706$

Kuzell, W. C., Seebach, L. M., Glover, R. P., and JACKMAN, A.: Treatment of gout with allopurinol and sulphinpyrazone in combination and with allopurinol alone, 634, *646, *647
Leukaemia, 655, 657, 668

Levin, N. W., and Abrahams, O. L.: Allopurinol in patients with impaired renal function, ${ }^{*} 649,681$

Liberman, U. A.: see Vries, A. de, etc., 691

Liver function, 625, 689, 698, *645, *704

Lithiasis, urinary, 677, 691,*705

Metabolism, 608, 615

Neoplasia, allopurinol in, 617, 651, 655, 657

OGryzlo, M. A., Urowitz, M. B., Weber, H. M., and Houpt, J. B.: Effects of allopurinol on gouty and $\vec{\omega}$ non-gouty uric acid nephropathy, 673, *622 bis, o $* 647, * 708$

Oxypurine, 602, 606, 684

Pericarditis, uraemic, *704

PoWell, L. W.: Effects of allopurinol on iron storage in the rat, $697, * 646, * 704$

Probenecid, 623, 689

Psoriasis and hyperuricaemia, 637, *647

Purine biosynthesis, 601

RAPADO, A.: Allopurinol in thiazide-induced hyper- $\mathrm{C}$ uricaemia, $660, * 647$ bis, *667

RundLes, R. W.: Metabolic effects of allopurinol and allo-xanthine, $615, * 622, * 645, * 646$

Effects of allopurinol on 6-mercaptopurine therapy

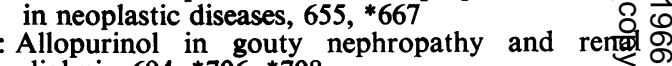
dialysis, $694, * 706, * 708$

Savage, O.: Opening address, 599

SCOTT, J. T.: Comparison of allopurinol and probenecid, $623, * 646$ bis, *647, 709

Seegmiller, J. E., and Frazier, P. D.: Biochemical ํํำ considerations of the renal damage of gout, 668, $\stackrel{\odot}{\square}$ *622,*645,*646,*650,*667,*704,*706,*707

SJöBERG, K.-H.: Allopurinol therapy of gout with renal $\overline{\mathrm{o}}$ complications, 688

Sperling, O.: see Vries, A. de, etc., 691

SEEBACH, L. M.: see Kuzell, W. C., etc., 634

Sulphinpyrazone, 634

Thiazide, $660, * 667$

Tophi, 628, 629, 635

Toxicity, 640

UdALL, V., *704

Uraemia in pericarditis, $* 704$

Uricosuria, 643, *648

Urowitz, M. B.: see Ogryzlo, M. A., etc., 673

Vries, A. De, Frank, M., Liberman, U. A., and Sperling, O.: Allopurinol in the prophylaxis of uric acid $\mathrm{N}$ stones, 691, *706, *707

WATTS, R. W. E.: Allopurinol in the therapy of neoplasia $N$ and blood diseases. Metabolic aspects, 655, *649,*650,*667,*706,*707

Weber, H. M.: see Ogryzlo, M. A., etc., 673

Xanthine, 602, 607, 609, 653, *667

6-mercaptopurine, $615,655, * 667$ 